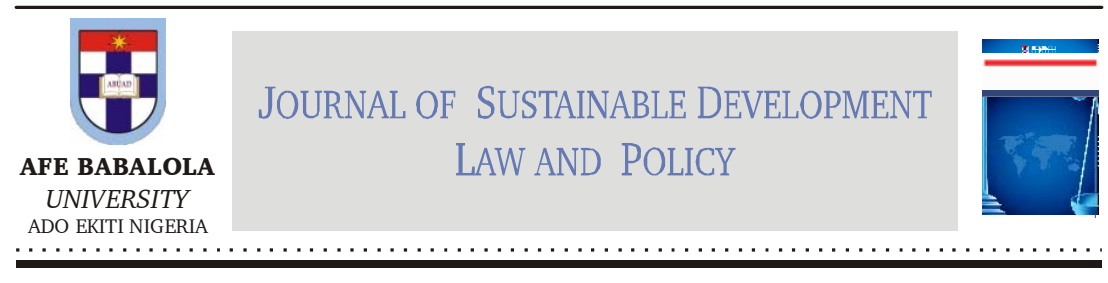

PUBLIC LECTURE

\title{
THE NIGERIAN BAR ASSOCIATION IN THE 21ST \\ CENTURY: THE INTEREST OF THE LEGAL PRACTITIONER AND THE COMPETING DUTY TO ACT IN THE PUBLIC INTEREST
}

\author{
Olawale Fapohunda*1
}

DOI: https://dx.doi.org/10.4314/jsdlp.v10i2.8

\section{INTRODUCTION}

I congratulate members of the Nigerian Bar Association (NBA) IkereEkiti Branch on the successful hosting of this First Law Week. I am particularly impressed by the professionalism and dedication with which the leadership of this branch put together this week. I will not be saying anything new if I add that the NBA Ikere Branch has truly come of age.

I should also quickly add that I consider it a privilege to be asked to deliver the First Chief Wole Olanipekun Public Lecture. The significance of this is not lost on me. Chief Olanipekun's contribution to legal practice and the legal profession needs no elaboration. He is an icon, a mentor, and an outstanding legal practitioner whose strides in the profession redefine the meaning of colossus. I am specifically pleased that I have the exclusive copyright to the First Chief Wole Olanipekun Public Lecture.

*1 Honourable Attorney-General \& Commissioner for Justice, Ekiti State, Nigeria. Text of the First Wole Olanipekun Public Lecture, delivered on 22 July 2019 at the Inaugural Law Week Nigerian Bar Association, Ikere-Ekiti Branch, at the Chief Wole Olanipekun Bar Centre, Ikere Ekiti. 
When I received the invitation to speak at this opening event, I shared it with my daughter, who is a final-year law student. In her words, she said it was as if the theme of this Conference was specifically made for me. This is because I had before the Paul Usoro Administration complained to her about the direction in which the Bar Association was heading and what appears to me to be the preoccupation with matters which, in my view, added little or no value to the strengthening of the profession or our citizen's confidence in the justice system.

It was just last Friday at a meeting in Lagos that I expressed my concern to some senior members of the Bar on what I perceived to be our lack of seriousness on the issue of speedy resolution of disputes. There is a broad consensus that two of the major challenges facing our justice system in Nigeria are that of delay and cost. Hardly does a day go by that the bar and bench at different platforms nationwide do not speak about the need to develop measures aimed at ensuring that we enable a system where disputes are resolved quickly while ensuring that litigation is made the last resort.

We speak of Alternative Dispute Resolution (ADR) in flowery language. Many of the States have accepted the idea of Multi-Door Court House and the cost of ADR and Mediation Conferences and Workshops in any given year, at least in the last five years, is more than the yearly budget of most State Judiciaries. Yet by some inexplicable reason the Bar and the Bench have made sure that the practice of ADR remains at best a theoretical concept with no real prospects of serious recognition at least within the profession.

To put this in concrete terms, neither the legal profession nor the judicial officers get any professional credit for resolving matters through $\mathrm{ADR}$. There is no provision in the successive guidelines for the conferment of the rank of Senior Advocate of Nigeria that specifically acknowledges the place of ADR in the conferment of the rank. The emphasis is on litigation. Also, despite the severally stated commitment of the National Judicial Council (NJC) to the speedy resolution of all disputes and the many seminars on the subject-matter by the National Judicial Institute (NJI), the NJC is yet to evolve a policy that gives judges credit in their productivity ratings for resolving matters through ADR.

Our current reality, therefore, is that the Bar and the Bench have foisted a fait accompli on the 21st century Nigerian lawyer. It is as if we are being told that we must litigate by force if we are to have any hope of professional progression. It is simply impossible to understand why the NBA and the Privileges Committee are reluctant to recognize those who 
have contributed to the ease of justice administration outside simply appearing in a specified number of cases and in most cases for fee-paying clients.

I am yet to get any convincing explanation on how arguing twenty cases in the High Court or superior court of record, five in the Court of Appeal and four in the Supreme Court contribute to the development of law and the administration of the justice system in Nigeria. The effect of a litigious legal system is that the justice system is haemorrhaging public confidence on a daily basis. This has dire consequences far beyond the law and practice. This is certainly not how to develop a 21st century legal system.

I should not be misunderstood to diminish the importance of litigation. The constitutional right of litigants to fair hearing should not be sacrificed for speed. In any case, litigation has an important place in the development of our jurisprudence. I am in favour of public interest litigation. This is an important tool for bringing justice to a large section of our population, particularly the poor and vulnerable. However, as I shall shortly discuss, the number of lawyers taking on public interest litigation in the face of a myriad issues facing us as a nation is too few to have any sustainable impact on the lives of majority of our people.

This litigation virus has not only infected our judgment on the importance of ADR but it has also infected the ability of the legal profession to respond strategically to issues facing us as a nation. The legal profession today remains largely insensitive, or worse still, unaware of the state of the nation. We have become commentators, or worse still, mere spectators in the evolving challenges that face our country.

It will probably be unfair to ask the legal profession to take the lead in proffering solutions to all the problems facing our country as a whole. However, it will be perfectly legitimate to expect the legal profession to provide leadership in the area of its competence, which is the administration of justice system.

One can be forgiven for assuming that the three arms of government are joined together in a conspiracy to undermine the sector. Nigeria is yet to witness a joined up and concerted effort by key justice institutions within the three arms of government to implement fundamental and farreaching reforms in the justice sector.

Indeed, since our return to democracy we have been served an unpalatable cocktail of meaningless and ad-hoc reforms that are neither sustainable nor responsive to the needs of the average Nigerian. The Executive has been unable and unwilling to undertake practical and 
sustainable interventions aimed at strengthening the justice system. The National Assembly and many of the State Houses of Assembly have been too busy fighting for their own survival to enact best practice laws that support the system, including reviewing existing laws to make them relevant to our needs. The Judiciary has largely remained ensnared by the British colonial mindset, holding fast to the relic of British traditions and practices that even the British have long jettisoned. In adjudication, we are more British than the British. The NBA itself has, for the most part, been preoccupied with succession wars and who leads the Association that it is getting dangerously close to being irrelevant to the needs of the generality of Nigerians, particularly the poor and vulnerable.

Such is the toxic effect of this cocktail, that majority of Nigerians have come to accept that a justice system that works in the interest of injustice is a normal feature of our everyday life. While the attention of much of the legal profession is focused on self-development, our justice institutions - the Judiciary, the Police, the Prisons, and Ministries of Justice - are today struggling to achieve their mandates.

\section{THE JUDICIARY}

The NBA, by its action and omission, has allowed itself to be hoodwinked into the reasoning that judicial corruption is the sole issue that affects the independence of the judiciary. Of course, this is an issue that currently dominates national discourse. It is now common news feature to hear some of our senior lawyers, especially those close to the seat of power, relegating the issue of conditions of service of judicial officers to the background.

Let me state right away that while I agree that there can be no justification for any form of judicial corruption, I am unable to accept that to serve on the bench is a call to national service and penury. The argument in some quarters that a judicial officer who is unable to survive on his merger salary should resign from the bench is ridiculous and unrealistic. It is also self-defeating to continue to preach integrity on the bench, without removing the temptation that comes with poor conditions of service. In my view, judicial salaries must be set at a comparatively high public-service level in order to remove both the temptation to corruption and public contemplation of the possibility of such temptation.

I cannot but wonder if the reaction of these lawyers will be the same if they know that between May 1999 and March 2011, the Federal Government reviewed the salaries and allowances of Public Servants 
and Political Office Holders on four occasions specifically in 2000, 2005, 2007 and 2011. However, the salaries of Judicial Officers were only reviewed twice during the same period. As a result, Judicial Officers have been on the same salary structure for more than 10 years.

\section{THE POLICE}

Much of the interventions of the NBA specifically at the Branches, on the state of security in Nigeria have for the most part been emotional, and media mediated. The legal profession has been unable to articulate a "lawyer inspired" debate on why we struggle with security in this country. Rather, we have joined the cacophony of uncoordinated voices reemphasizing what we all know without proffering solutions. Yes, there is insecurity in our land. Yes, we live in daily fear of kidnappers, robbers and criminal elements within the Fulani herdsmen. These are incontrovertible facts. The obvious next question should be what is the solution?

The NBA should be telling the Federal Government that our inability to adopt a criminal justice approach is an important obstacle to finding a sustainable solution to insecurity. The criminal justice approach is one that recognizes the important place of effective and efficient policing in maintaining law and order.

This invariably means that we need to take a closer look at our police force and ask ourselves whether the Nigeria Police, as it exists today, is capable of meeting our security needs. Added to this question must be an inquiry into whether in the last two decades or since our return to democracy, we have invested enough resources in the Police to expect a performance at the level required to secure our lives and property. The answers to these questions are obvious.

There is evidence of a deep-seated and strong resistance to the idea of police reforms in Nigeria. Indicative of the deeply entrenched resistance to police reform is the fact that there have been more than two decades of debate on policing and reform facilitated by several multiple highlevel committees. The findings and reports from these initiatives have largely gone unimplemented.

Public perception of corruption, impunity, absence of accountability, incompetence, and failure to control the law and order situation plague the Police Force. The immediate challenge is to reverse this perception and transform the Nigeria Police into a true public service institution capable of elevating the sense of security of Nigerians. 
This, in my respectful view, is the nature of conversation that the NBA should be having both internally and publicly. It is our ability to articulate issues that stand us tall among other professions that demonstrate our relevance to the plight of our people. Of course, the immediate problem is whether the legal profession is interested in or even understands the issues. Our recent tragic experiences must have taught us that the wig and gown offer us no protection against these criminal elements.

Meaningful Police reforms will require a wide range of interventions, including replacing the outdated Police Act 1968 with a new legislation that reflects Nigeria's constitutional imperatives and entails a wholesale review and redefinition of the role and function of the Nigeria Police.

Is the legal profession aware that, eighteen years into democracy, we do not have an appropriate legal framework for the Nigeria Police? The Bill for the Amendment of the Police Act is one of the casualties of politicking in the National Assembly. Rather than focus on strengthening the legal and institutional framework of the Nigeria Police, the National Assembly since 2000 has been preoccupied with the idea of a Police Trust Fund. Even if we give the Police all the money they need today, surely it is obvious that with a weak legal and institutional regime the monies so appropriated are likely to be wasted.

\section{THE NIGERIA PRISONS}

In my opinion, there is no institution that signposts the lack of interest of the legal profession in our criminal justice system than the Nigerian Prisons.

Over the years, the prisons have been a source of concern due to overcrowding, under-staffing, lack of adequate medical care, inadequate conditions for female and juvenile detainees, poor administration, long detention of those awaiting trial and limited access to legal advice and representation. These have frequently led to poor health conditions, including frequent jailbreaks.

With the total number of lawyers in Nigeria even excluding those not in active practice, how is it possible that the legal profession has been unable to find a durable solution to the problem of prison congestion, even if our intervention is limited to the provision of legal advice and representation to prisoners? Are we not concerned that with 125 NBA Branches spread across the 36 states of the federation and the FCT, there exists a large number of persons on remand in our 224 prison facilities 
without legal advice? Emphasis on advice, not representation.

Is the legal profession aware that the last time there was a review of the Prisons Law was in 1972? That the National Assembly has been unable to make progress on the Prisons Act Amendment Bill more than 20 years since it was first introduced in the House of Representatives?

Is the legal profession aware that the Ministry of Interior jointly supervises the Prisons Service and other paramilitary services like the Fire Service, the Immigration Service and the Civil Defence Corps? Do we realize that the duties of the Prisons Services are fundamentally different from those of the Fire Service, Immigration and Civil Defence Corps? Do we realize that a situation in which they are treated in the same way and administered by one administrative body will continue to militate against the efficiency and effectiveness of the Prisons Service?

Again, is there any interest within the profession to take up these issues that are so fundamental to our criminal justice system, or is it simply none of our business?

\section{MINISTRIES OF JUSTICE}

Recently, I led a team of lawyers in my Ministry to the Lagos State Ministry of Justice. Mr Governor advised that we should not sit down in AdoEkiti and imagine that life begins and ends here. We found that the Lagos State Ministry of Justice has taken giant strides in the administration of justice.

This is not the story nationwide. Poor remuneration of State Counsel, poor physical working conditions and limited funding of key interventions including prosecution of cases are key challenges. Many of the existing systems and process prevent the Justice Ministries from being effective and efficient.

Given that public legal practitioners constitute a large population of the organized members of the NBA, it is surprising that there is yet to be an NBA-inspired focused consultation on the situation of Law Officers in the Ministries of Justice nationwide. It is the NBA that is appropriately positioned to champion the campaign for a radical improvement in the conditions of service of State Counsels.

This is more so when it is realized that even in the face of the mentioned challenges, the Federal and State Ministries of Justice have initiated many of the reforms across the justice sector. I could mention a few: The Administration of Criminal Justice Act (ACJA), and the Law (ACJL) in several States. I dare add the Administration of Civil Justice 
Law - the contribution of the Ekiti State Ministry of Justice to Legal Practice and the Office of the Public Defender (OPD) Laws in several States; the Freedom of Information Act and the Laws in several States to mention a few. The Ministries of Justice have also produced important Policy Documents - The National Action Plan for the Promotion and Protection of Human Rights, the Sex Offenders Register - another Ekiti State Ministry of Justice contribution to the national discourse on preventing sexual violence, Prosecutors Guidelines and the Charter for Victims of Crime; the list goes on.

The interest of the NBA should be the delivery of quality legal services to the public.

\section{THE NIGERIAN BAR ASSOCIATION}

My concluding remarks will be focused on the Bar. The frenzy over who leads the NBA and the bitterness that often accompanies Bar elections has led to the weakening of the role of lawyers in facilitating and providing leadership to critical reforms for the transformation of our justice system. If this continues, it would not just be to the detriment of the profession, but also to the detriment of our justice system.

The ideal that lawyers should work to ensure that everyone can enjoy the benefits of the protection of the law, including those who are vulnerable by reason of limited means, limited education, their minority status or their gender, has long been a talking point within the legal profession. Regrettably, we have been guilty of all talk and limited action.

The unmet need for access to justice has led, among other things, to an increase in the number of unrepresented poor and indigent litigants. No one can reasonably suggest that we do not have enough lawyers in Nigeria. What we have, is a sad situation of too few lawyers working in public interest. The legal profession has to help meet that need if it is to retain the central position it is struggling to keep now in our justice system. If the profession is unable to provide that representation, it will not be long before the question is asked: "Why do we need lawyers?"

Our current reality is that public perception of lawyers and the justice system is at low levels. We need to respond to citizen's perception that lawyers are only interested in representing high fee-paying clients. This perception gives the impression of a profession that is selfish, self-centred and has lost touch with the concerns of Nigerians.

It will be good to see Senior Advocates in their hundreds represent some of the more than 40,000 awaiting trial persons in our prisons, 
many who have spent upwards of five to ten years awaiting trial, or poor individuals and communities who are frequent victims of official highhandedness.

Our President, Paul Usoro SAN, now needs to conduct legal practice along a different direction. This must be a direction that leads us to adopt different values and a renewed commitment to public interest.

As a first step, we need to reform the NBA elections system. We have shown by our conduct that we are unable to accept election outcomes even when the process is transparent and credible. We are not a political party. We should keep reminding ourselves that the sole purpose of any NBA office is to serve. We should work towards a consensus system. The disputes that accompany our elections ought to be an embarrassment to us all. How can we possibly have an opinion on INEC and its conduct of elections when we struggle with ours?

Secondly, and putting it bluntly, we need a leader with plenty to prove. The NBA leadership over the years has changed hands from one successful legal practitioner to another. We have had presidents who have achieved great heights in both public and private space, including the wealth that comes with such success.

It seems to me that the nature of the challenges we face in our profession, our legal system and the country as a whole, requires a leader who lives in the reality of our peoples' every day struggle. The Bar must return to the trenches. As those of us who come from the tradition of activism will know, the trenches is no place for the comfortable.

Thirdly, may I suggest at the risk of annoying my generation - those of us in the "about to retire" age group, that that we need a generational change in the leadership of the NBA. We need a leader from the digital age, with the knowledge, energy and zeal to reform our profession and challenge our frail legal system.

We need the NBA to lead the battle for the reform of our justice system. In this season of change, it is depressing that the wind of change has blown away from the justice sector. We should remove the NBA probono declaration from the shelf in the NBA secretariat, where it has been gathering dust and rededicate ourselves to working in the public interest.

Mr President, the time is right, and the time is now for you to take us in a different direction.

I thank you all for listening. 